第72回日本内科学会講演会 (1975年)

\title{
シンポジゥム 血液凝固と線溶
}

\author{
（1）血管内凝固症候群の病態生理 \\ 新渴大学医学部第一内科学教室 \\ 桜川 信男
}

\section{SYMPOSIUM ON THE BLOOD COAGULATION AND FIBRINOLYSIS \\ (1) PATHOPHYSIOLOGY OF DISSEMINATED INTRAVASCULAR COAGULATION SYNDROME}

Nobuo Sakuragawa, M.D.

The First Departmet of Internal Medicine, Niigata University School of Medicine

\section{I. 緒 言}

血管内凝固症候群 (intravascular coagulation syndrome，以下D I C）は先行する基礎疾患があ つて，流血中に凝固活性化物質が流入し，凝固因 子が活性化されてトロンビンが出現して種々の臟 器に血栓を生ずる:

D I Cの初期の研究は産科領域で行なわれ, 1947年Michigan大学のSchneider ${ }^{12)} に よ り$ 前置胎 盤早期剝離における症状は胎盤からの組織ト口 ソボブラスチン (tissue thromboplastin, 以下 T P L N ) に基づく凝固活性化によると判明し, Seeg$\mathrm{ers}^{\mathrm{a}}$ によりフィブリノーダン，第V因子，プロト ロンビンが減少することが判明した。内科的疾患 では急性前骨䯣球性白血病 (acute promyelocytic leukemia, 以下A P L) p全身性転移癌（胃癌, 卵 单癌，脺缄癌など) にD I Cが多発し，他に重症 感染症や重症肝疾患にもみられる。これらの疾患 で，障害をらけた組織からＴＰＬ N様物質が流血 中に入ると外因系凝固活性化が惹起され凝固因子 は消費されてトロンビンが出現する．出現したト ロンビンはプラスミン，トリプシンや活性第X因 子などととにserine proteaseといわ机フィブリ ノーゲンをフィブリンに転化させる作用以外に㠜 固線溶系因子や血小板にも影響を与光る，一方，
局所に血栓が生ずると末梢偱環障害がみられ，そ の血栓部位を通過する赤血球は柇態異常を呈して 破壊され，溶血を来たす(microangiopathic hemolytic anemia).

本稿ではA P L と胃癌の症例で, それらのD I

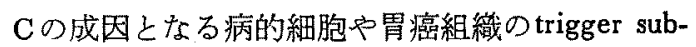
stance しての性状を追求し，D I C で血中に出 現するトロンビンと他の㠜固要因（㠜固線溶系因 子および血小板)との関連から，DＩＣの診断につ いて組織トロンボプラスチンを用いる従来のプロ トロンビン测定值と蛇毒 (echis carinatus venom, 以下 E C）を用いる湘定值との解離の意義につい てのベ, トロンビンとプラスミンが血中に存在す るD I Cの治療として抗凝固抗線溶作用をもつ Trasylolの大量投与が有効であることをのベる.

\section{II. 血管内凝固症候群の成因について} 新潟大学医学部第一内科で経験した D I C 症例 は A P L 34例, 転移性癌疾患25例, 産科的合併症 8 例の総計67例であるが，その5ちA P Lと転移 性胃癌についてそのD I Cの成因となる病的細胞 と胃癌組織の性状を追求した。

病的細胞りザートはプロトロンビンをトロンビ ンに転化する凝固活性（図1）とフィブリン平板 法咷よびフィブリン・フィルム法で線溶能を示す 


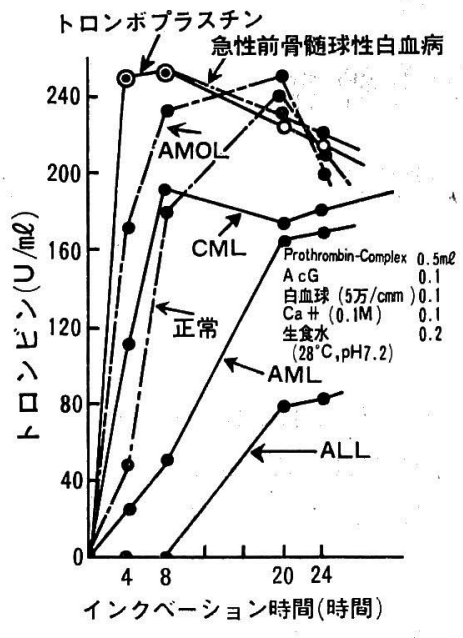

図 1. 白血病細胞リザートの凝固活性

ことが認められた。胃癌組織生食水抽出液にも同 様な成績が得られ, adenocarcinomaにcarcinoma simplexよりつよい活性が認められた4). 病的細 胞 リザートおよび胃癌抽出液をSephadex G-200 column chromatographyで分離すると 3 つの峰が みられ, 第 1 峰 (void volume) に凝固線溶活性が 認められた。これらの物質を家鬼へ注入すると定 型的な D I C 症状がみられ, 剖検で肺, 腎などに 血栓形成が認められた。この凝固活性は第X因子 活性化を介して行なわれ, 線溶活性はプラスミン 作用とプラスミノーゲンーアクチベータ作用を示 した。

III. serine proteaseとしてのトロンビンの凝 固線溶血小板へおよぼす影響

D I Cでtrigger substanceにより血中にトロン ビンが生ずるが，トロンビンは protease 作用でプ ロトロンビンを限定分解してプレトロンビンに転 化し， P R 部を分離する ${ }^{5)}$ 。プレトロンビンは通 常の T P L Nを用いるプロトロンビン測定法（プ ロトロンビン欠乏血浆を用いる一段法）によつて は測定されず，ECを用いる方法によつて測定さ れる．P R 部は抗トロンビンと抗活性第X因子作 用を示した。

純化トロンビンを純化プロトロンビンに反応さ せると，図2のようにトロンビンとプロトロンビ

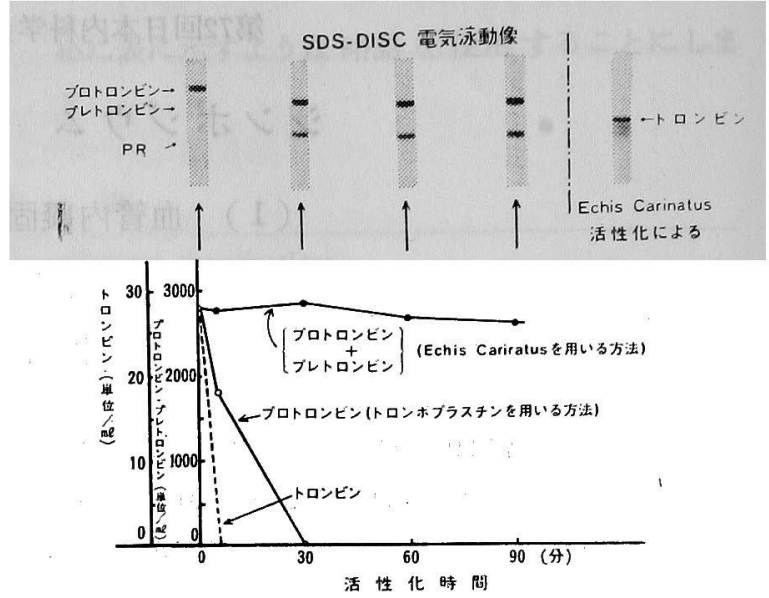

図 2.トロンビンによるプロトロンビンの活性化

ンは急速に失活して測定されなくなる。しかし， E C を用いるプロトロンビン測定法（プロトロン ビンとプレトロンビンを測定する）ではほぼ 100 \%測定把握され，SDS-disc電気泳動像でも E C よる活性化が確められた。

家兔へ純化トロンビン ${ }^{6)} 1000$ 単位を注入し, 注 入前と注入後 1 時間で活性化部分トロンボプラス チン時間（P T T) を測定すると注入後で延長 し，T P L Nを用いた方法でのプロトロンビン值 はECを用いたプロトロンビン值より約 $15 \%$ 低 值を示した。この血浆をDEAE-cellulose column chromatographyで分離すると抗活性第X因子作用 を強く示す峰が認められた．同様な結果を正常人 血浆と転移性胃癌患者血浆で検索して得た。

トロンビンの他凝固因子に拉よぼす影響につい て，トロンビン注入家鬼血浆で検討すると上記成 績のほかに第 $\mathrm{V}$ ，VII因子，アンチトロンビン，フ ィブリノーゲンは減少し, 血小板数は減少, 血小 板停滞率は低下した，線溶系ではプラスミノー ゲン, アンチプラスミンの減少, serial thrombin time (STT) の延長がみられた，不安定因子の第 V，VII因子はトロンビンKより障害され，一方卜 ロンビンにより線溶え進も惹起された（図 3 ).

トロンビンの 血小板機能への影響 は微量で短 時間反応させると血小板 A D P 凝集は促進された 


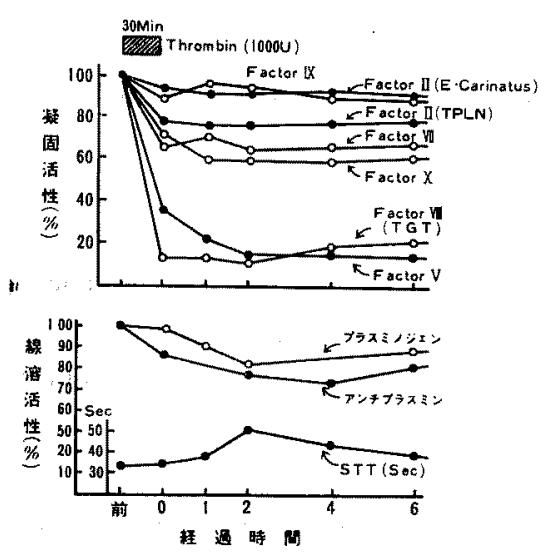

因 3、純化トロンビンの凝固線溶系因子に及ぼす 作用（in vivoウサギに注入）

が，高濃度では抑制された7)。

トロンビンの線溶作用をブラスミノジェン (一)フィプリン平板とプラスミノダン $(+)>$ ヘブリン平板で検索すると両者に溶解空がみら れ，プラスミノゲン（十）平板に大きく認められ た ${ }^{9)}$. 従つてトロンビンにはプラスミン作用とプ ラスミノジンンーアクチベータ作用が存在し, 線 溶系活性化はトロンビンの血中出現によつても 行なわれ，上記のトロンビン家鬼注入実験からも 実証された，線溶充進にはプラスミンが出現する が，プラスミンもserine proteaseであつて凝固因 子に影響を拈よぼず。

家鬼へurokinase（ミドリ十字社製） 100,000 単 位を注入すると高度の線溶元進がみとめら机，二 ーグロブリン溶解時間の短縮， S T T の延長，フ ィブリノーゲン減少が認められたが，凝固系では 第 $\mathrm{V}$ ， VIII⿴囗大因子，アンチトロンビン減少も著明で あつた。プロトロンビンはT P L Nを用いる万法 で80\%に減少して測定されたが，ECによつても ほ葟同值であり，プラスミンによるプレトロンビ ンの出現はないものと考えられる。従つて T P L $\mathrm{Nを}$ 用いる方法でのプロトロンビン值と $\mathrm{E} \mathbf{C} を$ 用 いる方法での値の解離10\%以上の存在は，一次線 溶元進とDI Cの鑑別に有用である.

家鬼へT P L N, 胃癌組織抽出液, A P L の病 的細胞リザート，活性第X因子，家鬼赤血球溶血

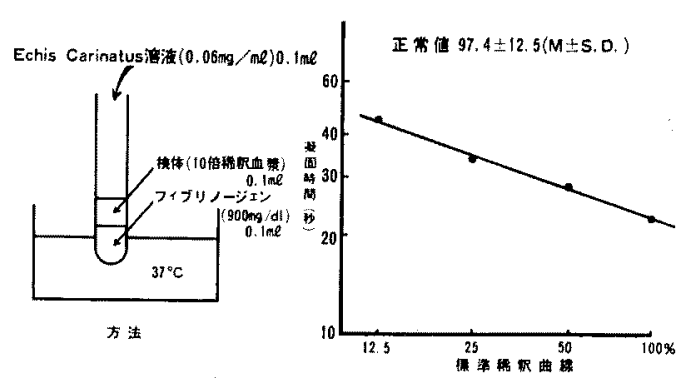

図 4.蛇艮Echis Carinatusを用いたプロトロンビン 測突法

液，乳酸，endotoxinを注入すると凝血所見でD I Cが認められ，T P L Nでのプロトロンビン值 と E Cでの值の解離が明白火認められた。一方。 線溶剤urokinaseや，トリプシンを注入すると同様 に凝固線溶，血小板系に障害が認められたが，剖 検での血栓形成はなく，上記のプロトロンビン值 の解離は存在しなかつた。

E C を用いるプロトロンビン測定法を図 4 亿示 したが，プロトロンビン值は正常人の標準曲線よ り per centとして表示される。

プロトロンビンを免疫学的に测定 (single radial immunodiffusion) すると， A P L での D I C症 例で $\mathrm{E} \mathrm{C}$ を用いたプロトロンビン值より多量に測 定されたが，全身性転移胃癌や産科的合併症で のDI C症例㧍上び肝硬変症では両者はほぽ同値 であり，A P L のでD I C症例ではE Cで测定さ れないプロトロンビンの存在る考えられる。トロ

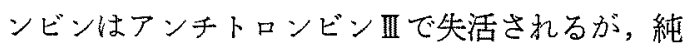
化したアンチトロンビン III ${ }^{83}$ ばトンビンよりも 活性第X因子を効率よく失活させ，血中でのト口 ソビン出現を抑制している。

\section{VI. 血管内凝固症候群の診断}

内科疾患での D I C発現は緩慢であり，頻回の 凝血異常の検索で彮断することが大切である。

DＩＣで血中に出現したトロンビンは，血栓形 成のほかにその protease 作用から他の凝固因子や 血小板を障害し，一方線溶九進をももたらす。

この凝血障害の度合は血中に流入する凝固活性 化物質の量や強さに基づくが，他方，生体の凝血 


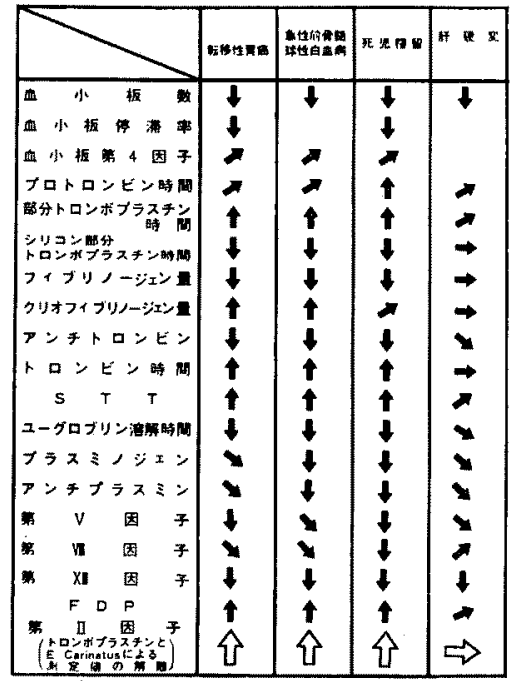

図 5. D I C 症例と肝硬変症の凝血学的榆查成縟

要素の産生度おょび網内系の処理能力によつても きりり,その変動は急激である.D I Cの診断はス クリーニングテストを血小板系，凝固系拐上び線 溶系について行ない，疑診をみた場合に確定診断 のためにさらに詳細な検索を行なう。この際， $\mathrm{E}$ Cを用いるプロトロンビン測定法は重要である。

A P L, 全身性転移胃癌, 産科的合併症でのD I C症例之凝血異常所見が近似する軽症肝硬変症 での成績を図 5 に示した，肝硬変症では肝に産生 される凝固因子(第 II， V， VII， IX，X，X因子） の低下による凝固異常と軽度の線溶穴進执よび血 小板減少はみられるが，フィプリノーゲンは減少 せず，第林因子はもしろ增加し，T P L Nを用い たプロトロンビン值と E Cでの值との解離は認め られずD I Cではない。

\section{V. 血管内疑固症候群の治療}

D I Cの治療に凝固線溶系の元進を阻止する目 的で，ヘパンと $\mathrm{t} \cdot \mathrm{AMCHA}$ (抗線溶剤)の併用が 行なわれている。 D I Cではへパリン $\operatorname{cofactor}(ア$ ンチトロンビン III 同じ）が減少し，血小板第 4 因子（ヘパリン中和作用を有する）が增加してへ パリンの有効性に差が生じ，一方フィブリノーゲ ンの極度の減少や血管炎の併発する場合にはへパ
リン投与には出血の危険がある。

Trasylolは抗凝固抗線溶作用を有し，抗線溶作 用が強力であるが，大量投与ではへパリン同様卜 ロンビン阻止効果を発揮し，またへパリンと異な つて補助因子を必要とせずに直接作用を示す。

家鬼一胃癌組織抽出液 (組織学的にadenocarcinoma mucocerulare) を注入して定型的な D I C を惹起させた後に，2.5万単位のTrasylolを注入 すると著しくバランスが崩壊されていた凝血異常 が急速に正常化した．臨床例として 産科合併症 (死児楾留) でのD I CにTrasylol 10万単位ずつ 3 回投与すると，第 $\mathrm{V}$, 㽤因子は徐々に回復增加 し，TＰＬNあるいはEＣを用いたプロトロンビ ン值の解離は縮小消隇し，止血をみた。線溶系で はSTTが正常化したが，F D Pの正常化には 2 日を要し，障害された血小板A D P 凝集能は 4 日 後に正常化した。 以上からTrasylolの大量投与は D I Cの治療に有効ともいえる.

\section{VI. 考 案}

D I Cには血中に凝固活性化物質が流入して凝 固因子が活性化されると同時に消費され，トロン ビンが生じて血栓形成をみるが，その際血小板が 用いられて減少する。一方, 血栓部位は虚血に尔 ら入つて該部から組織のプラスミノーゲンーアク チベータが放出されることで，2次綜溶の出現 が説明されて来た。従つてD I Cは消費性凝固症 (consumption coagulopathy) ともいわれた。 し かし，純化トロンビンには凝固活性とともに線溶 活性やエステラーゼ作用もあり，プラスミン，活 性第X因子やトリプシンとともにserine protease といわれる。このトロンビンはアンチトロンビン III゙失活されるが, progressive inhibitorといわれ

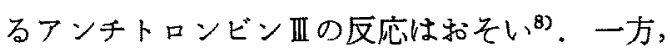
トロンビンの凝固因子へおよぼす作用は瞬間的で あつてプロトロンビン，第 $\mathrm{V}$ ，V亚因子タンパクを 障害して凝固充進を阻止するfeedback inhibition を示し，また血小板膜を障害してその機能を低下 させて血栓形成を阻止し，同時に線溶系を活性化 させて血栓溶解を推進させることが判る。これは 
生体に存在するhemostasisの面からみると合理的 な防衛機構とみられる：線溶元進で出現するプラ スミン多㠜固系と血小板へ作用して血恮形成を抑 制している。

トロンビン線溶活性化作用はD I CK物ける凝 固系之線溶系の同時発生を示し，一方 A P L の病 的細胞りザートや胃癌組織抽出液乃゙純系でプロト ロンビンをトロソビンに転化し，またこれら自体 に線溶活性化作用をみたことも凝固活性化上同時 に線溶え進をもたらすことになる。

このような凝固線溶の元進をみるD I Cの猃断 は凝血異常の多彩なことからも困奞なこともある が，血中にトロンビンが存在することで出現する プレトロンビンを測定検出すれば確実になる。て の点 E Cを用いるプロトロンビン測定法は重要で あり，DI C 之鑑別に困難な肝硬変症や一次線溶 に和ける出血現象も容易に判別されらる。

D I Cの治療について，央験的D I C家鬼や 産科合併症での症例でTrasylolを 30万単位（1日 量）投与すると出血症状の軽快ならびに凝血学的 障害の改善に著効がみられた。従来, 一パリンと t.AMCHAの併用が用いられているが，出血症状 が著しい症例での投与には抵抗を感し，また「治 療」の項でのべたように, フィブリノーゲンの娍 少，血管炎の存在，组小板第 4 因子の增加やへ八 リンcofactorの減少などの場合には使用量の有效 性からも問題があり，Trasylol大量投与がす寸る られ，その効果は10万単位 1 回投与で約 6 時間持 続した。

\section{VII. 結 論}

血管内凝固症候群の病態生理を血中に生ずるト ロソビンの作用の面から検索した。

(1) D I Cでは種々のtrigger substancesによ り凝固活性化が招こり, 凝固因子は用いられてト ロンビンが血中に出現する．AP L の病的細胞り ザートや胃癌組織抽出湤は㠜固活性と線溶活性を 有する。

（2）トロンビンは凝固活性（フィブリノージ ェンをフィブリンに転化）と線溶活性（プラスミ
ソ作用とプシスミノーゲンーアクチベータ作用） を有し，血管内凝固，楾溶活性化を同時に行な い，そのprotease作用で少量では血小板機能を九 准させるが增量して阻害作用を示し，第 $\mathrm{V} ，$ VII因 子を障害する，さらにプロトロンビン分子を限定 分解してプレトロンビンと阻謇因子（抗トロンビ ン作用と抗活性第X因子作用）を生ずる，プレト ロンビンは通常のＴＰＬＮを用いるプロトロンビ ン測定法では把握されないが，ECを用いる方法 で測定される，従つてDＩＣの診断にはT P L N を用いるプロトロンビン測定値と E Cによる值の 解離を求め机ぱよい。

（3）ＤＩ Cの治療は凝固線溶活性を有する卜 ロンビン蒙阻害することが大切である。抗線溶抗 凝固作用を有するTrasylolの大量投与は有効であ る。

\section{文献}

1) Schneider, C.L.: The active principle of placental toxin: Thromboplastin; its activation in blood. Amer. J. Physiol. 149: 123, 1947. -2) Schneider, C.L.: Etiology of fibrinopenia: Fibrination, defibrination. Ann. N.Y. Acad. Sci. 75: 634, 1959. -3) Johnson, J.F., W. H. Seegers and R.G. Braden: Plasma Ac-Globulin changes in placenta abruptio. Amer. J. clin. Path. 22: 322,1952 . -4) 桜川信男, 高橋蕉, 星山真理, 神保琵三，松岡松三，小出武比古，大西義久，北条 晴人：㠜固線溶系因子小精製と代謝（VII），D I C の引き金因子としての病的白血球拈よび胃癌組 緎の濒固線溶能、第16回臨床血液学会総会 (京都) に発表, 1974. -5) Seegers, W.H., D.A. Walz, J. Reuterby and L.E. McCoy: Isolation and some properties of thrombin-E and other prothrombin derivatives. Thrombosis Res. 4: 829, 1974. 一6) 兴川信男：プロトロンビン活性化機 橉について。目本臨床，32:901，1974。－7) Matsuoka, M., T. Watanabe, K. Koike and N. Sakuragawa: Platelet aggregation from interaction between washed platelets and purified thrombin, plasmin or trypsin. Thrombos. Diathes. Haemorrh (Suppl) LX: 185, 1974. -8) 高橋 藏, 桜川信 男，星山真理，神保長三，小池和夫，松岡松三，小 出武比古，大西落久，北条晴人: 凝固楾溶系因子 の精製と代謝 (VIII)，アンチトロンビンIIIの精製と その凝固線溶，血小板へお占任す影㮣，第37回日 本血液学会総会心発表，1975，一-9）桜川信男，小 出武比古：トロンビンの凝固線溶血小板へ扰よぼ 寸影響. 新渴医学会雑誌。 $89: 91,1975$. 